\title{
Short- and long-term consequences of larval stage exposure to constantly and ephemerally elevated carbon dioxide for marine bivalve populations
}

\author{
C. J. Gobler and S. C. Talmage \\ Stony Brook University, School of Marine and Atmospheric Sciences, 239 Montauk Hwy, Southampton, NY 11968, USA \\ Correspondence to: C. J. Gobler (christopher.gobler@ stonybrook.edu)
}

Received: 5 November 2012 - Published in Biogeosciences Discuss.: 14 November 2012

Revised: 11 February 2013 - Accepted: 18 February 2013 - Published: 5 April 2013

\begin{abstract}
While larval bivalves are highly sensitive to ocean acidification, the basis for this sensitivity and the longerterm implications of this sensitivity are unclear. Experiments were performed to assess the short-term (days) and longterm (months) consequences of larval stage exposure to varying $\mathrm{CO}_{2}$ concentrations for calcifying bivalves. Higher $\mathrm{CO}_{2}$ concentrations depressed both calcification rates assessed using ${ }^{45} \mathrm{Ca}$ uptake and RNA : DNA ratios in Mercenaria mercenaria and Argopecten irradians larvae with RNA: DNA ratios being highly correlated with larval growth rates $\left(r^{2}\right.$ $>0.9$ ). These findings suggested that high $\mathrm{CO}_{2}$ has a cascading negative physiological impact on bivalve larvae stemming in part from lower calcification rates. Exposure to elevated $\mathrm{CO}_{2}$ during the first four days of larval development significantly depressed A. irradians larval survival rates, while a 10-day exposure later in larval development did not, demonstrating the extreme $\mathrm{CO}_{2}$ sensitivity of bivalve larvae during first days of development. Short- (weeks) and longterm (10 month) experiments revealed that individuals surviving exposure to high $\mathrm{CO}_{2}$ during larval development grew faster when exposed to normal $\mathrm{CO}_{2}$ as juveniles compared to individuals reared under ambient $\mathrm{CO}_{2}$ as larvae. These increased growth rates could not, however, overcome size differences established during larval development, as size deficits of individuals exposed to even moderate levels of $\mathrm{CO}_{2}$ as larvae were evident even after 10 months of growth under normal $\mathrm{CO}_{2}$ concentrations. This "legacy effect" emphasizes the central role larval stage $\mathrm{CO}_{2}$ exposure can play in shaping the success of modern-day bivalve populations.
\end{abstract}

\section{Introduction}

The partial pressure of $\mathrm{CO}_{2}$ in the earth's atmosphere has risen by $40 \%$ since the Industrial Revolution, and concentrations are expected to double this century (IPCC, 2007). The ocean's ability to absorb $\mathrm{CO}_{2}$ has resulted in $41 \%$ of fossil fuel and cement manufacturing $\mathrm{CO}_{2}$ emissions being stored in the world's oceans (Sabine et al., 2004). This flux of $\mathrm{CO}_{2}$ has resulted in a reduction of ocean $\mathrm{pH}$, a decrease in carbonate ion availability, and an environment that is challenging calcifying organisms in marine ecosystems around the globe (Orr et al., 2005; Doney et al., 2009). In addition, many coastal ecosystems have become increasingly acidified via atmospheric carbon dioxide fluxes (Miller et al., 2009), the introduction of acidic river water (Salisbury et al., 2008), upwelling (Feely et al., 2008), and/or eutrophication-driven carbon loading (Cai et al., 2011).

Ocean acidification can have a wide range of negative effects on marine organisms from minor to severe. The earliest stages of development for numerous marine species can be the most sensitive to decreased $\mathrm{pH}$ and carbonate ion availability. For example, larval stages of bivalves (Miller al., 2009; Talmage and Gobler, 2009, 2010, 2011, 2012; Parker et al., 2010; Barton et al., 2012), corals (Albright et al., 2008), echinoderms (Dupont et al., 2010), pteropods (Comeau et al., 2010), and crustaceans (Walther et al., 2010) have all been shown to be negatively affected by the $\mathrm{CO}_{2}$ concentrations expected later this century in the world's oceans. Despite these findings, the mechanisms by which $\mathrm{CO}_{2}$ imparts negative effects on calcifying organisms are poorly understood. There have been few investigations of the biochemical effects of ocean acidification on marine bivalves. Moreover, direct 
measurements of calcification rates, the process most likely to be altered by ocean acidification, have been rarely made.

Most ocean acidification experiments conducted to date have administered a static exposure of specific $\mathrm{CO}_{2}$ concentrations to organisms (Doney et al., 2009). In a coastal ecosystem setting, however, it is likely that marine organisms experience dynamic $\mathrm{CO}_{2}$ concentrations. The effects of variable, compared to constant, exposure to high levels of $\mathrm{CO}_{2}$ on larval stage marine animals have rarely been investigated. This exposure may be important since $\mathrm{CO}_{2}$ concentrations in estuaries may vary tidally, diurnally, and with the succession of planktonic communities. Finally, longer-term implications of larval stage exposure to high $\mathrm{CO}_{2}$ for juvenile bivalves are poorly understood.

The objectives of this study were to examine the shortterm (days) and long-term (months) implications of larval stage exposure to high $\mathrm{CO}_{2}$ for calcifying bivalves. Mercenaria mercenaria (hard clams) and Argopecten irradians (bay scallop) larvae were grown under $p \mathrm{CO}_{2}$ of $\sim 250,390$, 750 , and $1500 \mu \mathrm{atm}$. Their growth was estimated from their RNA : DNA ratio, and their uptake of ${ }^{45} \mathrm{Ca}$ was quantified to estimate calcification rates. Additional experiments investigated the effects of variable high $\mathrm{CO}_{2}$ exposure on development of A. irradians larvae. A final set of experiments investigated the growth of post-set juvenile bivalves exposed to different levels of $\mathrm{CO}_{2}$ during larval development.

\section{Methods}

\subsection{General methods}

Five distinct experiments are presented in this manuscript: (1) measurements of calcium uptake rates in M. mercenaria and $A$. irradians, (2) measurements of RNA : DNA ratios and growth rates in $M$. mercenaria and A. irradians, (3) the effects of differing durations of high $\mathrm{CO}_{2}$ exposure on larval A. irradians survival, (4) the effects of larval exposure to high $\mathrm{CO}_{2}$ on larval and juvenile M. mercenaria survival, and (5) the effects of larval exposure to high $\mathrm{CO}_{2}$ on juvenile $A$. irradians growth. For all experiments, replicate $(n=4$ except for calcium uptake experiments) experimental beakers with bivalve larvae (described below) were maintained in water baths maintained at $24^{\circ} \mathrm{C}$ using commercially available aquarium heaters (Aquatic Eco-Systems, Inc., Florida, USA). Temperature was recorded every 6 min throughout experiments using in situ data loggers (Onset $\odot$ ); temperatures varied within $2.5 \%$ of target values. The experimental temperature $\left(24^{\circ} \mathrm{C}\right)$ is optimal for growth and survival of larvae from the two species used here (Kennedy, 1996; Kraeuter and Castagna, 2001; Cragg, 2006). All larvae were obtained from brood stock collected from the eastern extent of the Peconic Estuary, which experiences a modest range in $\mathrm{pH}$ and $p \mathrm{CO}_{2}$ $\left(\mathrm{pH}_{\mathrm{NBS}}=7.9-8.2 ; p \mathrm{CO}_{2}=300-500 \mu \mathrm{atm}, \mathrm{C}\right.$. J. Gobler, un- published), and were spawned at the East Hampton Town Shellfish Hatchery.

\subsection{Maintenance of $\mathrm{CO}_{2}$ levels}

A gas proportionator system (Cole-Parmer flowmeter system, multi-tube frame) was used to deliver $\mathrm{CO}_{2}$ gas to seawater treatments at different rates. The gas proportionator mixed appropriate flow rates of $5 \% \mathrm{CO}_{2}$ gas, low $\mathrm{CO}_{2}$ gas, and pressurized air $\left(\sim 390 \mu \mathrm{atm} \mathrm{CO}_{2}\right)$ to yield the concentrations of carbon dioxide desired for experiments at a net flow rate that turned over experimental vessels $>100$ times daily preventing equilibration with atmospheric $\mathrm{CO}_{2}$. Experiments performed with gases mixed via a proportionator as described here generate nearly identical seawater chemistry and larval responses obtained from tanked gases premixed at specific $\mathrm{CO}_{2}$ levels (Talmage and Gobler, 2010). For experiments, the $\mathrm{CO}_{2}$ gas mixtures from the proportionator system were continuously delivered to the bottom of $1 \mathrm{~L}$ high density polyethylene beakers with polycarbonate lids. With continuous bubbling, all treatment vessels remained saturated with respect to oxygen $\left(\sim 7 \mathrm{mg} \mathrm{L}^{-1}\right)$. To quantify precise $\mathrm{CO}_{2}$ levels attained in experimental treatments, aliquots were removed and analyzed during experiments with an EGM-4, Environmental Gas Analyzer (PP Systems) system that quantified total dissolved inorganic carbon levels after separating the gas phase from seawater using a Liqui-Cel Membrane (Membrana). This instrument provided a methodological precision of $\pm 4 \%$ for replicated measurements of total dissolved inorganic carbon and provided full recovery (104 $\pm 5 \%)$ of Dr. Andrew Dickson's (University of California San Diego, Scripps Institution of Oceanography) certified reference material for total inorganic carbon in seawater (Batch $102=2013 \mu \mathrm{mol}$ dissolved inorganic carbon $\mathrm{kg}$ seawater ${ }^{-1}$ ). Levels of $\mathrm{CO}_{2}$ were calculated based on measured levels of total inorganic carbon, $\mathrm{pH}$ (mol kg seawater ${ }^{-1}$; NBS), temperature, salinity, phosphate, silicate, and first and second dissociation constants of carbonic acid in seawater according to Roy et al. (1993) using the program CO2SYS (http://cdiac.ornl.gov/ftp/co2sys/). Daily measurements of $\mathrm{pH}$ with a high sensitivity potentiometric electrode (Thermo Scientific Orion 3-Star ${ }^{\mathrm{TM}}$ Benchtop $\mathrm{pH}$ meter; \pm 0.002 ) calibrated prior each use with NIST/NBS traceable standards indicated experimental vessels maintain a constant $\mathrm{pH}$ level throughout experiments $(<0.5 \%$ RSD within treatments). Spectrophotometric measurements of $\mathrm{pH}$ made using $m$-cresol purple as described by Dickson et al. (2007) and corrected for scale ( $\sim 0.13$ units; Dickson, 1993) were never significantly different from those obtained with the potentiometric electrode. 
Table 1. Mean temperature, $\mathrm{pH}$, carbonate chemistry, total alkalinity, and salinity ( 1 SD) during the three-level carbon dioxide experiments for calcium uptake with Mercenaria mercenaria and Argopecten irradians larvae.

\begin{tabular}{|c|c|c|c|}
\hline Parameter & Near pre-industrial $\mathrm{CO}_{2}$ & Ambient, present-day $\mathrm{CO}_{2}$ & Elevated $\mathrm{CO}_{2}$ \\
\hline \multicolumn{4}{|l|}{ Mercenaria mercenaria } \\
\hline Temperature $\left({ }^{\circ} \mathrm{C}\right)$ & $24 \pm 0.8$ & $24 \pm 0.8$ & $24 \pm 0.8$ \\
\hline $\mathrm{pH}_{\mathrm{NBS}}$ & $8.2 \pm 0.051$ & $8.08 \pm 0.076$ & $7.800 \pm 0.013$ \\
\hline$p \mathrm{CO}_{2}(\mu \mathrm{atm})$ & $248.3 \pm 21.03$ & $372.6 \pm 39.48$ & $781.6 \pm 29.99$ \\
\hline$\Omega_{\text {calcite }}$ & $3.10 \pm 0.13$ & $2.59 \pm 0.21$ & $1.53 \pm 0.13$ \\
\hline$\Omega_{\text {aragonite }}$ & $1.98 \pm 0.39$ & $1.69 \pm 0.21$ & $0.99 \pm 0.13$ \\
\hline $\mathrm{C}_{\mathrm{T}}\left(\mu \mathrm{mol} \mathrm{L}{ }^{-1}\right)$ & $1117 \pm 37.95$ & $1365 \pm 54.22$ & $1458 \pm 23.33$ \\
\hline $\mathrm{CO}_{3}^{2-}\left(\mu \mathrm{mol} \mathrm{L}^{-1}\right)$ & $117.8 \pm 3.96$ & $104.8 \pm 35.78$ & $60.5 \pm 15.632$ \\
\hline Total alkalinity $\left(\mathrm{A}_{\mathrm{T}}\right)$ & $1412.7 \pm 112.5$ & $1516 \pm 74.56$ & $1528 \pm 32.44$ \\
\hline Salinity & $28.0 \pm 1.0$ & $28.0 \pm 1.0$ & $28.0 \pm 1.0$ \\
\hline \multicolumn{4}{|l|}{ Argopecten irradians } \\
\hline Temperature $\left({ }^{\circ} \mathrm{C}\right)$ & $24 \pm 0.8$ & $24 \pm 0.8$ & $24 \pm 0.8$ \\
\hline $\mathrm{pH}_{\mathrm{NBS}}$ & $8.2 \pm 0.047$ & $8.08 \pm 0.061$ & $7.810 \pm 0.009$ \\
\hline$p \mathrm{CO}_{2}(\mu \mathrm{atm})$ & $237.3 \pm 5.32$ & $396.5 \pm 21.43$ & $753.2 \pm 19.04$ \\
\hline$\Omega_{\text {calcite }}$ & $2.94 \pm 0.25$ & $2.60 \pm 0.24$ & $1.55 \pm 0.11$ \\
\hline$\Omega_{\text {aragonite }}$ & $1.89 \pm 0.40$ & $1.71 \pm 0.18$ & $1.01 \pm 0.11$ \\
\hline $\mathrm{C}_{\mathrm{T}}\left(\mu \mathrm{mol} \mathrm{L}{ }^{-1}\right)$ & $1220 \pm 42.22$ & $1327 \pm 26.56$ & $1438.6 \pm 15.45$ \\
\hline $\mathrm{CO}_{3}^{2-}(\mu \mathrm{mol} \mathrm{L}-1)$ & $121.3 \pm 5.98$ & $101.9 \pm 48.55$ & $61.0 \pm 17.843$ \\
\hline Total alkalinity $\left(\mathrm{A}_{\mathrm{T}}\right)$ & $1352.7 \pm 42.76$ & $1518 \pm 55.56$ & $1511 \pm 36.44$ \\
\hline Salinity & $28.0 \pm 1.0$ & $28.0 \pm 1.0$ & $28.0 \pm 1.0$ \\
\hline
\end{tabular}

Table 2. Mean temperature, $\mathrm{pH}$, carbonate chemistry, total alkalinity, and salinity ( $\pm 1 \mathrm{SD})$ during the three-level carbon dioxide for calcium uptake over time for Argopecten irradians larvae.

\begin{tabular}{llll}
\hline Parameter & Near pre-industrial $\mathrm{CO}_{2}$ & Ambient, present-day $\mathrm{CO}_{2}$ & Elevated $\mathrm{CO}_{2}$ \\
\hline Argopecten irradians & & & \\
Temperature $\left({ }^{\circ} \mathrm{C}\right)$ & $24 \pm 0.8$ & $24 \pm 0.8$ & $24 \pm 0.8$ \\
$\mathrm{pH}_{\mathrm{NBS}}$ & $8.201 \pm 0.022$ & $8.041 \pm 0.042$ & $7.801 \pm 0.013$ \\
$p \mathrm{CO}_{2}(\mu \mathrm{\mu tm})$ & $242.4 \pm 19.221$ & $402 \pm 21.268$ & $764.7 \pm 19.658$ \\
$\Omega_{\text {calcite }}$ & $3.01 \pm 0.14$ & $2.38 \pm 0.32$ & $1.51 \pm 0.16$ \\
$\Omega_{\text {aragonite }}$ & $1.94 \pm 0.46$ & $1.54 \pm 0.31$ & $0.97 \pm 0.26$ \\
$\mathrm{C}_{\mathrm{T}}\left(\mu \mathrm{mol} \mathrm{L}{ }^{-1}\right)$ & $1196 \pm 45.76$ & $1334 \pm 35.62$ & $1430 \pm 28.45$ \\
$\mathrm{CO}_{3}^{2-}\left(\mu \mathrm{mol} \mathrm{L}{ }^{-1}\right)$ & $118.4 \pm 26.32$ & $94.2 \pm 28.65$ & $59.5 \pm 20.01$ \\
Total alkalinity $\left(\mathrm{A}_{\mathrm{T}}\right)$ & $1381.1 \pm 30.05$ & $1470.2 \pm 43.02$ & $1501 \pm 43.88$ \\
Salinity & $28.0 \pm 1.0$ & $28.0 \pm 1.0$ & $28.0 \pm 1.0$ \\
\hline
\end{tabular}

\subsection{Effects of varying $\mathrm{CO}_{2}$ exposure on calcification rates}

M. mercenaria and A. irradians larvae were grown at three levels of $p \mathrm{CO}_{2}$ : a high level $(\sim 750 \mu \mathrm{atm})$, predicted for the year 2100; a modern level $(\sim 390 \mu \mathrm{atm})$; and lower, near pre-industrial level $(\sim 250 \mu \mathrm{atm})$ through the veliger and pediveliger stages. Precise $\mathrm{CO}_{2}$ levels and complete carbonate chemistry from this experiment appear in Tables 1 and 2. One-liter beakers were filled with $0.2 \mu \mathrm{m}$ filtered seawater from eastern Shinnecock Bay, New York, USA, and within hours of fertilization larvae were distributed to each treatment beaker at a concentration of $\sim 400 \mathrm{~L}^{-1}$, consistent with post-spawning densities in estuaries (Carriker, 2001). Larvae were fed an ideal food source, Isochrysis galbana (Tahitian strain, T-Iso), at a density known to maximize bivalve larval growth and survivorship through metamorphosis $\left(4 \times 10^{4}\right.$ cells mL ${ }^{-1}$ daily; Castell and Mann, 1994; Cragg, 2006; Talmage and Gobler, 2009). Cultures of I. galbana were maintained in exponential phase growth using standard culture conditions. To promote high survivorship, all containers in contact with larvae were never exposed to chemicals (Talmage and Gobler, 2009); to discourage the growth of bacteria during experiments, an antibiotic solution (SigmaAldrich No. 4083, 5000 units of Penicillin, $5 \mathrm{mg}$ of Streptomycin, and $10 \mathrm{mg}$ of Neomycin per milliliter of solution) 
was added to each beaker at $1 \%$ its original concentration (100-fold dilution of stock) at the beginning of each experiment and at the time of each water change (approximately 2 times weekly). This antibiotic mixture at this concentration has been shown to have no negative effects on the growth and survivorship of shellfish larvae (Talmage and Gobler, 2009). Some experiments presented here (Fig. 1) were repeated without antibiotic treatments and yielded no difference in bivalve larval performance suggesting that neither the antibiotics nor the bacteria in seawater appreciable altered results. Every three days, larvae were gently poured onto a $64 \mu \mathrm{m}$ mesh, and all larvae from each beaker $(n=6$, per treatment, 3 beakers for veligers, and 3 beakers for pediveligers at each $\mathrm{CO}_{2}$ level) were removed and transferred into a new beaker with new filtered seawater, food, and antibiotics within a $15 \mathrm{~min}$ period for each beaker.

To measure calcification rates during the veliger and pediveliger stage for Mercenaria mercenaria larvae (3 and $10 \mathrm{~d}$ post-fertilization) and Argopecten irradians larvae (12 and $15 \mathrm{~d}$ post-fertilization), 250 larvae per treatment were removed and placed into $125 \mathrm{~mL}$ polyethylene bottles with $100 \mathrm{~mL}$ new filtered seawater; temperature was maintained at $24^{\circ} \mathrm{C}$ and the bottles were continuously bubbled to achieve the same $\mathrm{CO}_{2}$ levels the larvae had been grown under until that point. Differences in the rate of calcification of larvae exposed to differing levels of $\mathrm{CO}_{2}$ were assessed using a ${ }^{45} \mathrm{Ca}$ isotope tracer method (Ho and Zubkoff, 1980). High specific activity, $9.25 \times 10^{6} \mathrm{~Bq},{ }^{45} \mathrm{Ca}$ was added to $\sim 100 \mathrm{~mL}$ of filtered seawater with 250 larvae in 4 replicated, polypropylene $125 \mathrm{~mL}$ Nalgene bottles resulting in a final concentration of $3.7 \times 10^{3} \mathrm{~Bq} \mathrm{~mL}^{-1}$. A killed-control bottle was established at each level of $\mathrm{CO}_{2}$ via the addition of glutaraldehyde to a final concentration of $2 \%$. After $24 \mathrm{~h}$, bottles were gently gravity filtered onto $20 \mu \mathrm{m}$ polycarbonate membranes. For $A$. irradians larvae, time series uptake experiments were also made during the veliger and pediveliger stages when subsamples of larvae were removed at $1,2,4,6$, and $12 \mathrm{~h}$ to obtain an estimate of calcium uptake over time. All larvae retained on filters were rinsed with filtered seawater to remove surface adsorbed ${ }^{45} \mathrm{Ca}$, transferred to scintillation vials, and digested with $1 \mathrm{~mL}$ of concentrated $\mathrm{HNO}_{3}(15.8 \mathrm{~N})$ for $1 \mathrm{~h}$, after which $10 \mathrm{~mL}$ of Ultima Gold ${ }^{\mathrm{TM}}$ scintillation cocktail was added. Beta activity of the samples was counted on a PerkinElmer Tri-Carb 1600 liquid scintillation counter with the discriminator window optimized for ${ }^{45} \mathrm{Ca}$ detection. The weight-specific calcium uptake rate per individual was determined by the following equation:

$\mathrm{CaU}=\frac{\left[(\mathrm{dpm})_{\mathrm{l}}-(\mathrm{dpm})_{\mathrm{d}}\right] \cdot \mathrm{Ca}_{\mathrm{m}}}{(\mathrm{dpm})_{\mathrm{m}} \cdot t \cdot L}$

where $\mathrm{CaU}$ is the calcium uptake rate $\left(\mathrm{ng} \mathrm{Ca}\right.$ larva $\left.^{-1} \mathrm{hr}^{-1}\right)$, $(\mathrm{dpm})_{1}$ radioactivity of live larvae, $(\mathrm{dpm})_{\mathrm{d}}$ the radioactivity of killed larvae (which represents non-biological factors including background, ion-exchange and isotope absorption), $\mathrm{Ca}_{\mathrm{m}}$ the calcium content of unit medium water in $\mathrm{mg} \mathrm{L}^{-1},(\mathrm{dpm})_{\mathrm{m}}$
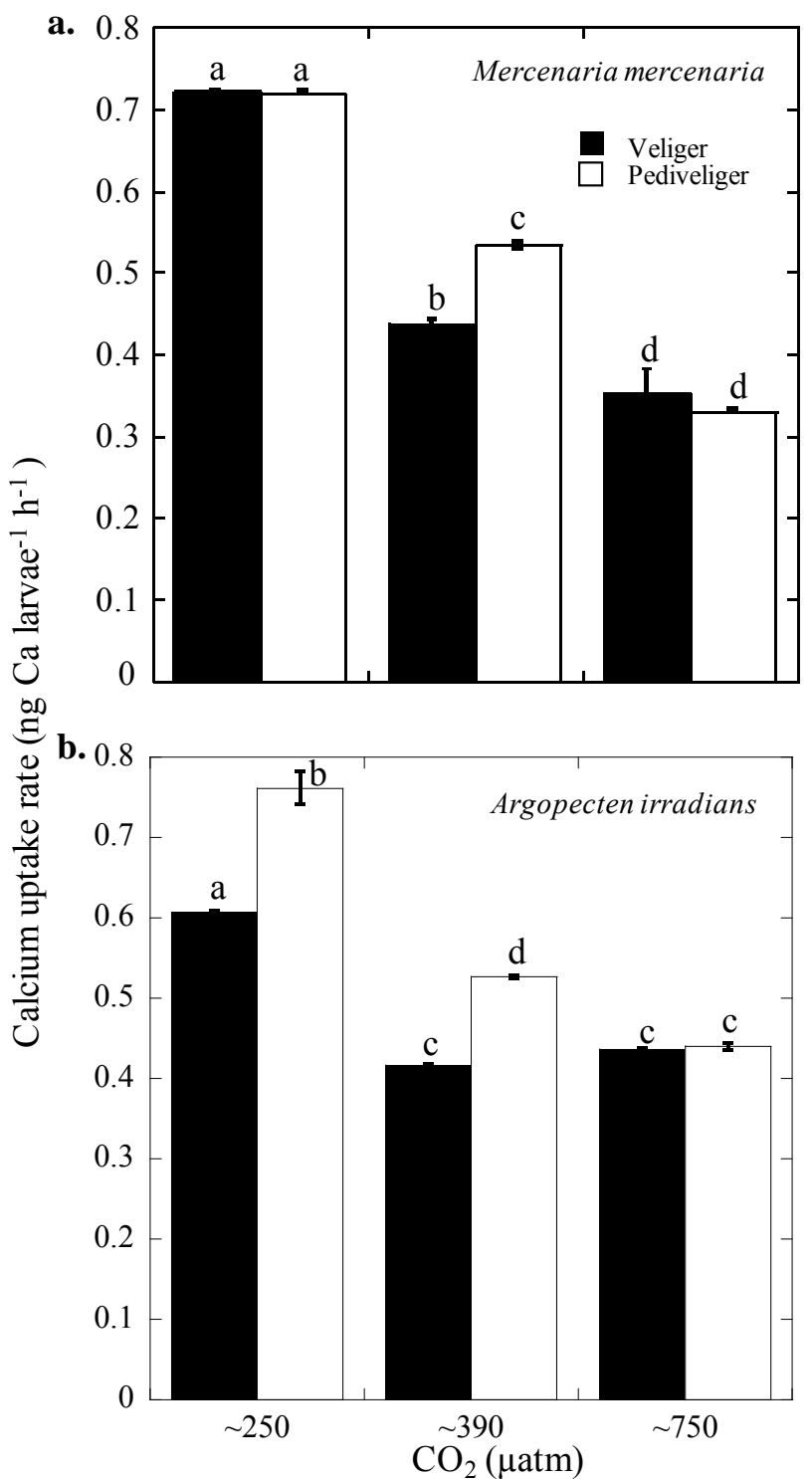

Fig. 1. Mean calcium uptake \pm 1 standard deviation for larvae from two developmental stages of Mercenaria mercenaria (veligers from day 3, and pediveligers from day 10) and Argopecten irradians larvae (veligers from day 12, and pediveligers from day 15). Larvae were grown under $p \mathrm{CO}_{2}$ of approximately 250,390 , and $750 \mu \mathrm{atm}$ $\mathrm{CO}_{2}$ (Table 1). Letters indicate significant differences revealed from Tukey post hoc multiple comparisons, $p \leq 0.05$ for all.

the radioactivity of unit medium water, $t$ the length of the incubation (days) and $L$ the number of larvae per beaker.

This equation is based on the assumption that there is no significant discrimination by larvae for ${ }^{45} \mathrm{Ca}$ and ${ }^{40} \mathrm{Ca}$ uptake. Since bivalves exposed to high levels of $\mathrm{CO}_{2}$ and low levels of $\mathrm{pH}$ can dissolve (Green et al., 2009; Talmage and Gobler, 2010), these should be considered net calcification rates. Calcium content of water was estimated by the ratio of its salinity to that of typical oceanic water of 35, which has 408 ppm of $\mathrm{Ca}^{2+}$ (Sverdrup, 1942). 
Table 3. Temperature, $\mathrm{pH}_{\mathrm{NBS}}$, carbonate chemistry, total alkalinity, and salinity ( $\pm 1 \mathrm{SD}$ ) during the four-level carbon dioxide experiments with Mercenaria mercenaria and Argopecten irradians larvae.

\begin{tabular}{|c|c|c|c|c|}
\hline Parameter & Near pre-industrial $\mathrm{CO}_{2}$ & Ambient, present-day $\mathrm{CO}_{2}$ & Year $2100 \mathrm{CO}_{2}$ & Year $2200 \mathrm{CO}_{2}$ \\
\hline \multicolumn{5}{|l|}{ Mercenaria mercenaria } \\
\hline Temperature $\left({ }^{\circ} \mathrm{C}\right)$ & $24 \pm 0.52$ & $24 \pm 0.52$ & $24 \pm 0.52$ & $24 \pm 0.52$ \\
\hline $\mathrm{pH}_{\mathrm{NBS}}$ & $8.171 \pm 0.022$ & $8.052 \pm 0.036$ & $7.801 \pm 0.004$ & $7.532 \pm 0.021$ \\
\hline$p \mathrm{CO}_{2}(\mu \mathrm{atm})$ & $247.1 \pm 6.231$ & $380.0 \pm 33.02$ & $742.3 \pm 9.111$ & $1516 \pm 31.21$ \\
\hline$\Omega_{\text {calcite }}$ & $5.31 \pm 0.47$ & $4.53 \pm 0.41$ & $2.82 \pm 0.05$ & $1.67 \pm 0.05$ \\
\hline$\Omega_{\text {aragonite }}$ & $3.42 \pm 0.30$ & $2.92 \pm 0.26$ & $1.82 \pm 0.03$ & $1.08 \pm 0.03$ \\
\hline $\mathrm{C}_{\mathrm{T}}\left(\mu \mathrm{mol} \mathrm{L}{ }^{-1}\right)$ & $1646 \pm 94.21$ & $1831 \pm 52.34$ & $1947 \pm 21.33$ & $2108 \pm 18.06$ \\
\hline $\mathrm{CO}_{3}^{2-}\left(\mu \mathrm{mol} \mathrm{L}^{-1}\right)$ & $208.0 \pm 20.22$ & $178.0 \pm 16.03$ & $111.0 \pm 1.806$ & $66.0 \pm 1.904$ \\
\hline Total alkalinity $\left(\mathrm{A}_{\mathrm{T}}\right)$ & $1938 \pm 117.3$ & $2070 \pm 66.42$ & $2080 \pm 22.63$ & $2127 \pm 49.71$ \\
\hline Salinity & $28.0 \pm 1.0$ & $28.0 \pm 1.0$ & $28.0 \pm 1.0$ & $28.0 \pm 1.0$ \\
\hline \multicolumn{5}{|l|}{ Argopecten irradians } \\
\hline Temperature $\left({ }^{\circ} \mathrm{C}\right)$ & $24 \pm 0.51$ & $24 \pm 0.52$ & $24 \pm 0.52$ & $24 \pm 0.52$ \\
\hline $\mathrm{pH}_{\mathrm{NBS}}$ & $8.170 \pm 0.026$ & $8.041 \pm 0.044$ & $7.801 \pm 0.005$ & $7.530 \pm 0.011$ \\
\hline$p \mathrm{CO}_{2}(\mu \mathrm{atm})$ & $244.1 \pm 4.006$ & $386.5 \pm 40.04$ & $738.9 \pm 9.941$ & $1529 \pm 35.05$ \\
\hline$\Omega_{\text {calcite }}$ & $5.18 \pm 0.06$ & $4.55 \pm 0.47$ & $2.81 \pm 0.06$ & $1.66 \pm 0.05$ \\
\hline$\Omega_{\text {aragonite }}$ & $3.34 \pm 0.35$ & $2.94 \pm 0.30$ & $1.81 \pm 0.04$ & $1.07 \pm 0.03$ \\
\hline $\mathrm{C}_{\mathrm{T}}\left(\mu \mathrm{mol} \mathrm{L}{ }^{-1}\right)$ & $1613 \pm 53.54$ & $1850 \pm 30.98$ & $1941 \pm 25.54$ & $2101 \pm 9.221$ \\
\hline $\mathrm{CO}_{3}^{2-}\left(\mu \mathrm{mol} \mathrm{L}^{-1}\right)$ & $202.0 \pm 23.42$ & $180.0 \pm 18.44$ & $111.0 \pm 2.341$ & $66.02 \pm 1.911$ \\
\hline Total alkalinity $\left(\mathrm{A}_{\mathrm{T}}\right)$ & $1899 \pm 35.24$ & $2090 \pm 50.01$ & $2075 \pm 26.84$ & $2146 \pm 11.21$ \\
\hline Salinity & $28.0 \pm 1.0$ & $28.0 \pm 1.0$ & $28.0 \pm 1.0$ & $28.0 \pm 1.0$ \\
\hline
\end{tabular}

\subsection{Effects of varying $\mathrm{CO}_{2}$ on RNA : DNA ratios and growth rates}

To assess RNA : DNA ratios of $M$. mercenaria and A. irradians larvae, individuals were grown at four levels of $p \mathrm{CO}_{2}$ : a high level $(\sim 1500 \mu \mathrm{atm})$, predicted for the year 2200; a mid-level ( $\sim 750 \mu \mathrm{atm})$, predicted for the year 2100 ; a modern level ( $\sim 390 \mu \mathrm{atm})$; and a near pre-industrial level ( $\sim 250 \mu \mathrm{atm})$. The general experimental setup followed the description above; precise $\mathrm{CO}_{2}$ levels and complete carbonate chemistry from this experiment appear in Table 3. At the end of the larval stage ( $\sim$ three weeks of development), the size of individual larvae ( $n=20$ per beaker) was quantified microscopically using ImageJ software as described by Talmage and Gobler (2010). The ratio between ribonucleic acid (RNA) and deoxyribonucleic acid (DNA) content in larvae was assessed (Clemmesen, 1994). This approach provides an RNA : DNA ratio, which has been used in other marine organisms, especially fish larvae, to estimate growth and nutritional condition, with elevated ratios being associated with fast growing individuals (Malzahn et al., 2003; Malzahn et al., 2007). Larvae $(n=15)$ were removed from each treatment beaker, poured onto a sieve, macerated using a Pellet Pestle Motor, heated to $50{ }^{\circ} \mathrm{C}$ for $15 \mathrm{~min}$, and then frozen in $-80^{\circ} \mathrm{C}$ for at least $90 \mathrm{~min}$. Nucleic acids from groups of larvae were extracted using a modified CTAB (cetyltrimethylammonium bromide) technique (Dempster et al., 1999) and quantified using Quant-iT ${ }^{\mathrm{TM}}$ RiboGreen RNA and Quant$\mathrm{iT}^{\mathrm{TM}}$ PicoGreen DNA assay kits (Invitrogen), according to manufacturer's protocol. RiboGreen RNA and PicoGreen DNA are ultra-sensitive fluorescent nucleic acid stains for quantifying RNA and DNA, respectively, in solution. RiboGreen also binds DNA; therefore, complete DNase digestion of samples preceded analysis of RNA. RNA and DNA concentrations in the extracted samples were quantified by measuring fluorescence using an Applied Biosystems 7300 realtime PCR system-genetic analyzer and compared to a standard curve of nucleic acids.

\subsection{Effects of varying $\mathrm{CO}_{2}$ exposure on survival of larval bivalves}

An experiment was conducted to investigate the effects of two levels of $p \mathrm{CO}_{2}(\sim 390$ and $\sim 750 \mu \mathrm{atm})$ exposure on the growth and survival of $A$. irradians larvae over a $19 \mathrm{~d}$ period. The general experimental setup followed the description above; precise $p \mathrm{CO}_{2}$ levels and complete carbonate chemistry from this experiment appear in Table 4. The experiment began with 15 treatment vessels at each $p \mathrm{CO}_{2}$ level ( $~ 390$ and $\sim 750 \mu \mathrm{atm})$. About every three days beginning on day 4 until day 13, three treatment vessels were switched from $\sim 750$ to $\sim 390 \mu \mathrm{atm}$, and three treatment vessels were switched from $\sim 390$ to $\sim 750 \mu$ atm $\mathrm{CO}_{2}$. Three vessels were maintained at $390 \mu \mathrm{atm}$, and three were maintained at $750 \mu \mathrm{atm}$ for the entire experiment so that $A$. irradians larvae experienced exposure time to each $p \mathrm{CO}_{2}$ level, which ranged from $0-19 \mathrm{~d}$. In the end, this experimental design 
Table 4. Temperature, $\mathrm{pH}$, carbonate chemistry, total alkalinity, and salinity $( \pm 1 \mathrm{SD})$ during the two-level carbon dioxide varying exposure experiment with Argopecten irradians larvae.

\begin{tabular}{lll}
\hline Parameter & Normal $\mathrm{CO}_{2}$ & Elevated $\mathrm{CO}_{2}$ \\
\hline Argopecten irradians & & \\
Temperature $\left({ }^{\circ} \mathrm{C}\right)$ & $24 \pm 0.6$ & $24 \pm 0.6$ \\
$\mathrm{pH}_{\mathrm{NBS}}$ & $8.08 \pm 0.049$ & $7.82 \pm 0.015$ \\
$p \mathrm{CO}_{2}(\mu \mathrm{atm})$ & $372.6 \pm 23.21$ & $732.5 \pm 29.02$ \\
$\Omega_{\text {calcite }}$ & $2.66 \pm 0.47$ & $1.58 \pm 0.17$ \\
$\Omega_{\text {aragonite }}$ & $1.71 \pm 0.28$ & $1.02 \pm 0.38$ \\
$\mathrm{C}_{\mathrm{T}}\left(\mu \mathrm{mol} \mathrm{L}{ }^{-1}\right)$ & $1364.1 \pm 32.44$ & $1432.6 \pm 46.87$ \\
$\mathrm{CO}_{3}^{2-}\left(\mu \mathrm{mol} \mathrm{L} \mathrm{L}^{-1}\right)$ & $104.7 \pm 23.24$ & $62.2 \pm 20.03$ \\
$\mathrm{Total}_{\text {alkalinity }}\left(\mathrm{A}_{\mathrm{T}}\right)$ & $1516.3 \pm 66.54$ & $1508 \pm 52.56$ \\
Salinity & $28.0 \pm 1.0$ & $28.0 \pm 1.0$ \\
\hline
\end{tabular}

exposed some larvae high $p \mathrm{CO}_{2}$ early in their development only while others were exposed later in their development.

To assess the implications of larval stage $p \mathrm{CO}_{2}$ exposure for juvenile stage $M$. mercenaria, larvae were grown at two $p \mathrm{CO}_{2}$ levels: $\sim 390$ and $1500 \mu \mathrm{atm}$. The general experimental setup followed the description above; precise $\mathrm{CO}_{2}$ levels and complete carbonate chemistry from this experiment appear in Table 5. After $24 \mathrm{~d}$ of development, 40 individuals that had metamorphosed into early juvenile stages were transferred from $\sim 390$ to $\sim 1500$ and another 40 individuals were transferred from $\sim 1500$ to $\sim 390 \mu$ atm $\mathrm{CO}_{2}$; individuals were pooled from replicated treatment beakers. Early stage juveniles were cared for as described above for larvae and were monitored until day 36 .

\subsection{Long-term growth experiment}

To assess the longer-term (months) implications of larval stage exposure to high $\mathrm{CO}_{2}$, Argopecten irradians larvae $(n=1000)$ were grown at three $\mathrm{CO}_{2}$ concentrations $(\sim 250$, 390 , and $750 \mu \mathrm{atm}$ ) for their entire larval cycle and early days as a juvenile. The general experimental setup followed the description above; precise $\mathrm{CO}_{2}$ levels and complete carbonate chemistry from this experiment appear in Table 6. Following standard shellfish hatchery protocols, after $35 \mathrm{~d}$ of development, all metamorphosed juveniles were quantified and placed on $64 \mu \mathrm{m}$ mesh sieves submerged in seawater where they received a continuous flow of coarsely filtered $(100 \mu \mathrm{m}$ nylon) seawater from Shinnecock Bay, NY, USA, which has been reported to have $\mathrm{pH}$ levels ranging from 7.66-8.01 (NBS scale; Gobler and Talmage, 2009). At 47 d, individuals were moved into Three Mile Harbor, East Hampton, NY, USA, which is more oligotrophic than Shinnecock Bay with "near-normal" $\mathrm{pH}$ values (7.9-8.2 NBS scale). At Three Mile Harbor, individuals were placed in mesh $(500 \mu \mathrm{m})$ bags in a cage so as to receive ample water flow and food but to exclude predators. Bags were changed, and the size of all individuals was recorded monthly over a ten-month period. Spe-
Table 5. Temperature, $\mathrm{pH}$, carbonate chemistry, total alkalinity, and salinity ( $\pm 1 \mathrm{SD}$ ) during the four-level carbon dioxide experiments with Mercenaria mercenaria larvae for varying $\mathrm{CO}_{2}$ exposure experiment.

\begin{tabular}{lll}
\hline Parameter & Normal $\mathrm{CO}_{2}$ & Elevated $\mathrm{CO}_{2}$ \\
\hline $\begin{array}{lll}\text { Mercenaria mercenaria } \\
\text { Temperature }\left({ }^{\circ} \mathrm{C}\right)\end{array}$ & $24 \pm 0.4$ & $24 \pm 0.4$ \\
$\mathrm{pH}_{\mathrm{NBS}}$ & $8.08 \pm 0.037$ & $7.58 \pm 0.054$ \\
$p \mathrm{CO}_{2}(\mu \mathrm{atm})$ & $407.5 \pm 27.832$ & \pm 17.996 \\
$\Omega_{\text {calcite }}$ & $2.93 \pm 0.32$ & $1.02 \pm 0.08$ \\
$\Omega_{\text {aragonite }}$ & $1.87 \pm 0.39$ & $0.65 \pm 0.12$ \\
$\mathrm{C}_{\mathrm{T}}\left(\mu \mathrm{mol} \mathrm{L}{ }^{-1}\right)$ & $1492 \pm 42.22$ & $1592 \pm 23.28$ \\
$\mathrm{CO}_{3}^{2-}\left(\mu \mathrm{mol} \mathrm{L}^{-1}\right)$ & $114.5 \pm 24.3$ & $40.0 \pm 15.4$ \\
Total alkalinity $\left(\mathrm{A}_{\mathrm{T}}\right)$ & $1650 \pm 36.56$ & $1611 \pm 37.81$ \\
Salinity & $28.0 \pm 1.0$ & $28.0 \pm 1.0$ \\
\hline
\end{tabular}

cific growth rates were estimated using the following equation: [ln(final size $)-\ln ($ initial size $)] /$ change in time. Hundreds of individuals from each treatment were deployed for this experiment, and individual animals were considered independent replicates for this experiment.

\subsection{Statistical analyses}

Statistical analyses were performed with SYSTAT $13^{\odot}$ (2009, Systat Software, Inc). Percent survival values were arc-sin square root transformed before statistical analyses. Two-way analyses of variance (ANOVAs) and post hoc Tukey multiple comparison tests were performed to assess differences among calcification rates at each $\mathrm{CO}_{2}$ level and larval stage. Differences in RNA: DNA ratios, growth rates, and survival percentages among $\mathrm{CO}_{2}$ levels were examined with one-way ANOVAs and post hoc Tukey multiple comparison tests. Data sets not meeting the assumptions of normality and homogeneity were ranked prior to analyses as a non-parametric approach. Values reported in the results sections are means \pm standard deviations.

\section{Results}

\subsection{Calcium uptake rates by $M$. mercenaria and A. irradians larvae}

For Mercenaria mercenaria larvae grown under three levels of $\mathrm{CO}_{2}(\sim 250,390$, and $750 \mu \mathrm{atm})$, there was a significant effect of $\mathrm{CO}_{2}$ concentration on calcium uptake for the veliger stage and for the pediveliger stage $(p<0.05$; two-way ANOVA; Fig. 1a). For M. mercenaria on day 3, veliger larvae calcium uptake rates were $0.72 \pm 0.001,0.44 \pm 0.005$,

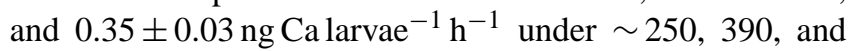
$750 \mu$ atm $\mathrm{CO}_{2}$ respectively (Fig. 1a). Ten-day-old M. mercenaria pediveligers under $\sim 250,390$, and $750 \mu \mathrm{atm} \mathrm{CO}_{2}$ had similarly decreasing calcium uptake rates of $0.72 \pm 0.002$, 
Table 6. Temperature, $\mathrm{pH}$, carbonate chemistry, total alkalinity, and salinity $( \pm 1 \mathrm{SD})$ during the three-level carbon dioxide experiments for Argopecten irradians larvae growth before deployment in the estuary for juvenile growth.

\begin{tabular}{llll}
\hline Parameter & Near pre-industrial $\mathrm{CO}_{2}$ & Ambient, present-day $\mathrm{CO}_{2}$ & Elevated $\mathrm{CO}_{2}$ \\
\hline Argopecten irradians & & & \\
Temperature $\left({ }^{\circ} \mathrm{C}\right)$ & $24 \pm 0.7$ & $24 \pm 0.7$ & $24 \pm 0.7$ \\
$\mathrm{pH} \mathrm{NBS}_{\mathrm{NBS}}$ & $8.20 \pm 0.067$ & $8.08 \pm 0.072$ & $7.81 \pm 0.009$ \\
$p \mathrm{CO}_{2}(\mu \mathrm{atm})$ & $231.3 \pm 34.538$ & $373.1 \pm 29.78$ & $755.9 \pm 14.226$ \\
$\Omega_{\text {calcite }}$ & $2.86 \pm 0.53$ & $2.66 \pm 0.55$ & $1.55 \pm 0.09$ \\
$\Omega_{\text {aragonite }}$ & $1.94 \pm 0.37$ & $1.71 \pm 0.50$ & $1.00 \pm 0.43$ \\
$\mathrm{C}_{\mathrm{T}}\left(\mu \mathrm{mol} \mathrm{L} \mathrm{L}^{-1}\right)$ & $1141 \pm 98.33$ & $1365.7 \pm 56.79$ & $1443.8 \pm 38.92$ \\
$\mathrm{CO}_{3}^{2-}\left(\mu \mathrm{mol} \mathrm{L}{ }^{-1}\right)$ & $112.9 \pm 25.35$ & $104.8 \pm 37.37$ & $61.3 \pm 14.54$ \\
$\mathrm{Total}_{\text {alkalinity }}\left(\mathrm{A}_{\mathrm{T}}\right)$ & $1320.9 \pm 119.3$ & $1518.1 \pm 43.36$ & $1516.4 \pm 47.54$ \\
Salinity & $28.0 \pm 1.0$ & $28.0 \pm 1.0$ & $28.0 \pm 1.0$ \\
\hline
\end{tabular}

$0.53 \pm 0.005$, and $0.33 \pm 0.002 \mathrm{ng} \mathrm{Ca}$ larvae ${ }^{-1} \mathrm{~h}^{-1}$ (Fig. 1a). Calcification rates did not differ between stages $(p>0.5$; two-way ANOVA; Fig. 1a).

Argopecten irradians larvae displayed a similar pattern of decreasing calcium uptake under increasing $\mathrm{CO}_{2}$ concentrations. For A. irradians there was a significant effect of $\mathrm{CO}_{2}$ on calcium uptake for day 12 , veliger larvae as well as for day 15 , pediveliger larvae $(p<0.001$; two-way ANOVA). There was also a significant effect of developmental stage and an interactive effect of $\mathrm{CO}_{2}$ and developmental stage on A. irradians calcium uptake $(p<0.05$ for both; two-way ANOVA; Fig. 1b). With an increase in $\mathrm{CO}_{2}$ concentrations from $\sim 250$ to $390 \mu \mathrm{atm}, A$. irradians veliger larvae calcium uptake rates decreased from $0.61 \pm 0.003$ to $0.42 \pm 0.001 \mathrm{ng} \mathrm{Ca}$ larvae ${ }^{-1} \mathrm{~h}^{-1}$ (although levels did not decreased dramatically at $750 \mu$ atm (Fig. 1b)). A. irradians pediveliger larvae calcium uptake also decreased with increasing $\mathrm{CO}_{2}$ concentrations from $0.76 \pm 0.02,0.53 \pm 0.001$, and $0.44 \pm 0.004 \mathrm{ng} \mathrm{Ca}$ larvae ${ }^{-1} \mathrm{~h}^{-1}$ at $\sim 250,390$, and $750 \mu \mathrm{atm}$ $\mathrm{CO}_{2}$ (Fig. 1b). A separate experiment found that A. irradians veliger larval uptake of calcium was linear over $12 \mathrm{~h}$ (Fig. 2). Using this approach, A. irradians veliger larvae at $250 \mu \mathrm{atm}$ had the greatest uptake rates $(0.90 \mathrm{ng} \mathrm{Ca}$ larvae ${ }^{-1} \mathrm{~h}^{-1}$; Fig. 2) while, at $\sim 390$ and $\sim 750 \mu$ atm $\mathrm{CO}_{2}$, A. irradians larvae calcium uptake rates decreased to 0.52 and $0.29 \mathrm{ng} \mathrm{Ca}$ larvae ${ }^{-1} \mathrm{~h}^{-1}$, respectively (Fig. 2).

\subsection{M. mercenaria and A. irradians RNA : DNA ratios and growth rates}

To understand the effects of $\mathrm{CO}_{2}$ on larval development, RNA : DNA ratios and shell diameter-based growth rates were quantified. Mercenaria mercenaria larvae (day 24) and Argopecten irradians larvae (day 20) both displayed stepwise decreases in both measurements of growth with increasing $\mathrm{CO}_{2}$ concentrations. $\mathrm{CO}_{2}$ concentrations had a significant effect on RNA: DNA for $M$. mercenaria $(p<0.001$; ANOVA). At $\sim 250 \mu$ atm $\mathrm{CO}_{2}$, the RNA: DNA ratio was $1.43 \pm 0.07$ for $M$. mercenaria larvae and progressively de-

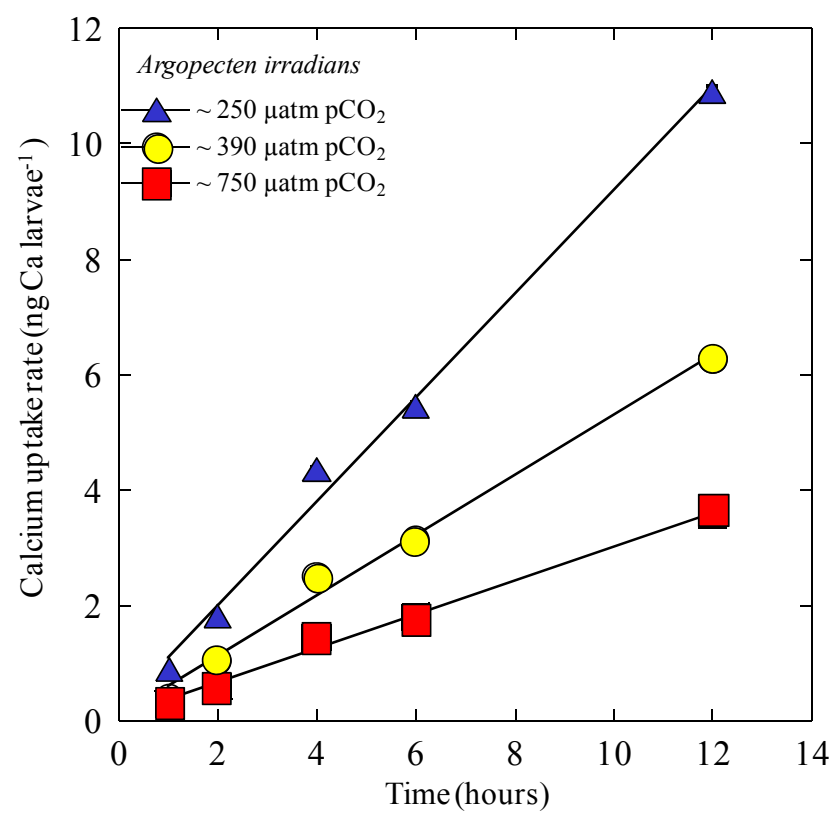

Fig. 2. Mean ( $\pm 1 \mathrm{SD}$ ) calcium uptake rates over $12 \mathrm{~h}$ for $A r$ gopecten irradians larvae (veligers from day 12). Larvae were grown under $\mathrm{CO}_{2}$ concentrations of approximately 250, 390, and $750 \mu$ atm $\mathrm{CO}_{2}$ (Table 2), $\mathrm{n}=4$ per treatment. Regressions corresponding to each treatment are listed in the legend. Regressions are $250 \mu$ atm $\mathrm{CO}_{2}, y=0.19+0.90 \times\left(R^{2}=0.99\right), \sim 390 \mu$ atm $\mathrm{CO}_{2}$, $y=0.05+0.52 \times\left(R^{2}=0.99\right)$, and $\sim 750 \mu \mathrm{atm} \mathrm{CO}_{2}, y=0.06+$ $0.29 \times\left(R^{2}=0.99\right)$.

creased to $0.39 \pm 0.05,0.31 \pm 0.05$, and $0.21 \pm 0.06$ at 390 , 750, and $1500 \mu \mathrm{atm} \mathrm{CO}_{2}$ (Fig. 3). A. irradians also displayed decreasing RNA : DNA with increasing $\mathrm{CO}_{2}$ (Fig. 3). When $\mathrm{CO}_{2}$ concentrations increased from $\sim 250$ to 390 to 750 to $1500 \mu \mathrm{atm}, \mathrm{RNA}$ : DNA for A. irradians changed from $1.02 \pm 0.07$ to $0.49 \pm 0.17$ to $0.20 \pm 0.03$ to $0.25 \pm 0.04$ respectively (Fig. 3). 


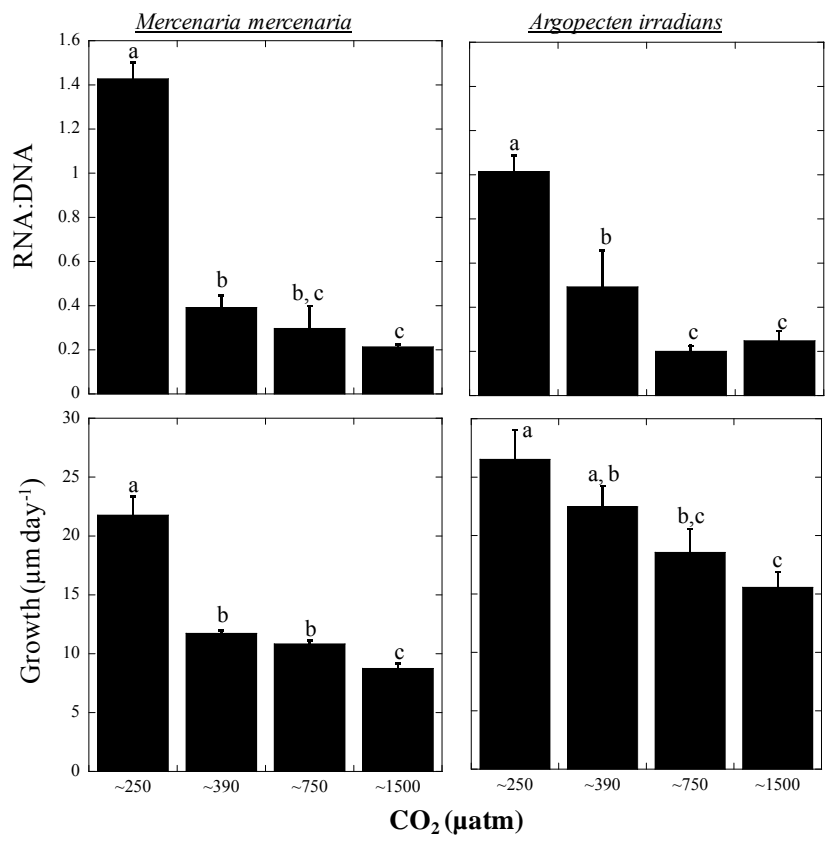

Fig. 3. Mean RNA : DNA ( $\pm 1 \mathrm{SD})$ and mean, shell-based, specific growth rates $( \pm 1 \mathrm{SD})$ for Mercenaria mercenaria (day 24) and Argopecten irradians (day 20) larvae, $n=15$ larvae per treatment. Larvae were grown under $\mathrm{CO}_{2}$ concentrations of approximately 250, 390, and $750 \mu$ atm $\mathrm{CO}_{2}$ (Table 3). Letters indicate significant differences revealed from Tukey post hoc multiple comparisons, $p \leq 0.05$ for all.

The second proxy for growth, changes in shell diameter, followed a similar pattern as RNA:DNA. $\mathrm{CO}_{2}$ concentrations had a significant effect on $M$. mercenaria larval shell growth $(p<0.001$; ANOVA $)$ and A. irradians larval shell growth $(p<0.001$; ANOVA; Fig. 3$)$. With increasing $\mathrm{CO}_{2}$ from $\sim 250,390,750$ to $1500 \mu \mathrm{atm}, M$. mercenaria larvae growth decreased from $21.8 \pm 1.58,11.7 \pm 0.20$, $10.9 \pm 0.28$, to $8.76 \pm 0.38 \mu \mathrm{m} \mathrm{d}^{-1}$, respectively (Fig. 3). A. irradians larvae followed the same pattern of decreasing growth from $26.5 \pm 2.53,22.5 \pm 1.75,18.6 \pm 2.02$, and $15.6 \pm 1.32 \mu \mathrm{m} \mathrm{d}^{-1}$ under $\mathrm{CO}_{2}$ concentrations of $\sim 250,390$, 750 and 1500 respectively (Fig. 3). Finally, there was the high degree of linear correlation between RNA : DNA ratios and shell-based growth rates of M. mercenaria and A. irradians larvae $\left(r^{2}=0.92 ; p=0.08\right.$ and $r^{2}=0.99 ; p<0.01$, respectively).

\subsection{A. irradians survival under varying exposure to high $\mathrm{CO}_{2}$}

To assess how variable $\mathrm{CO}_{2}$ exposure affected larval bivalve survival, Argopecten irradians larvae were exposed to normal $\mathrm{CO}_{2}(\sim 390 \mu \mathrm{atm})$ or high $\mathrm{CO}_{2}(\sim 750 \mu \mathrm{atm})$ and switched to either the higher (for vessels at $390 \mu \mathrm{atm} \mathrm{CO}_{2}$ ) or normal (for vessels at $750 \mu \mathrm{atm} \mathrm{CO}_{2}$ ) $\mathrm{CO}_{2}$ concentration. The duration of exposure to high $\mathrm{CO}_{2}$ significantly af-

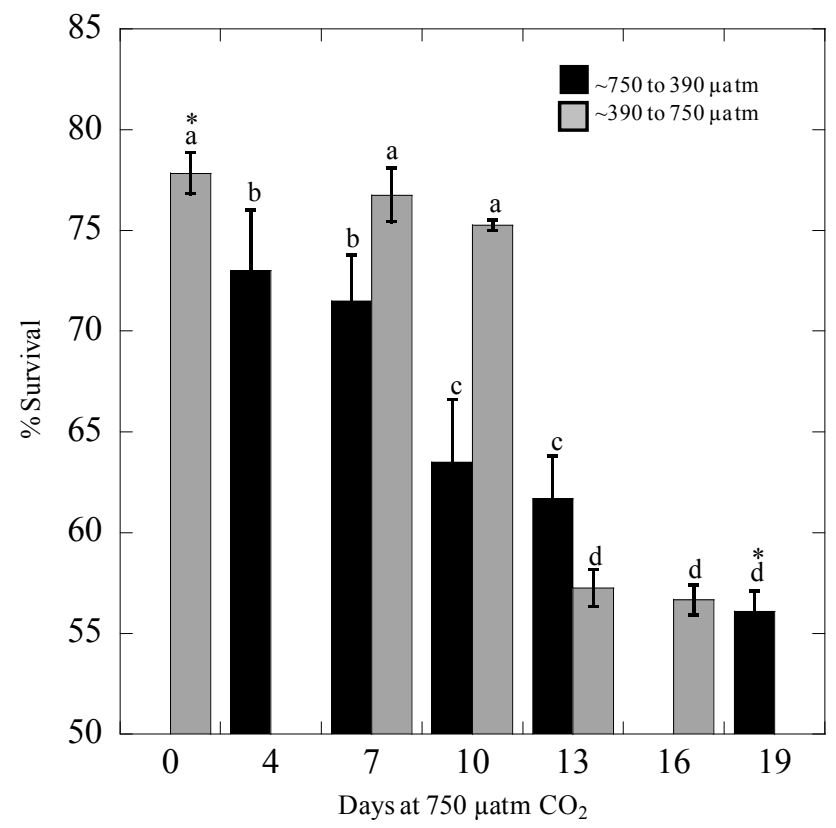

Fig. 4. Survival \pm standard deviation of Argopecten irradians larvae under varying days of exposure to approximately $750 \mu \mathrm{atm} \mathrm{CO}_{2}$ (Table 4). Black and grey bars represent larvae that were switched from high to low and low to high $\mathrm{CO}_{2}$, respectively $(n=4$ per treatment). Letters indicate significant differences revealed from Tukey post hoc multiple comparisons, $p \leq 0.05$ for all. ${ }^{*}$ indicates these individuals only experienced either $390 \mu \mathrm{atm}$ or $750 \mu \mathrm{atm}$ and were never switched.

fected larval survival ( $p<0.001$; ANOVA; Fig. 4). A. irradians larvae, which developed exclusively under 390 and $750 \mu \mathrm{atm} \mathrm{CO}_{2}$, displayed survival rates of $78 \pm 1.0 \%$ and $56 \pm 1.0 \%$, respectively (Fig. 4). In contrast, individuals that began their development at high $\mathrm{CO}_{2}$ and were switched to lower $\mathrm{CO}_{2}$ after $4,7,10$, and 13 days displayed survival rates of $73 \pm 3.0,71.5 \pm 2.3,63.5 \pm 3.1$, and $61.7 \pm 2.2 \%$, respectively (Fig. 4). Importantly, even three days of exposure to $750 \mu \mathrm{atm} \mathrm{CO}_{2}$ significantly reduced larval survival rates compared to constant exposure to $390 \mu$ atm (Fig. 4). A. irradians larvae that began at $\sim 390 \mu \mathrm{atm} \mathrm{CO}_{2}$ and were switched to $750 \mu \mathrm{atm} \mathrm{CO}_{2}$ after $7,10,13$, and $16 \mathrm{~d}$ displayed survival rates of $76.8 \pm 1.3,75.3 \pm 0.25$, and $57.25 \pm 0.9$, and $56.7 \pm 0.8 \%$, respectively (Fig. 4). Of this group, only individuals exposed for 13 and $16 \mathrm{~d}$ displayed survival that was significantly lower than the constant $390 \mu$ atm level (Fig. 4).

\subsection{M. mercenaria survival under varying exposure to high $\mathrm{CO}_{2}$}

An experiment was conducted to investigate the effects of changing $\mathrm{CO}_{2}$ exposure on survival by moving Mercenaria mercenaria from higher to lower concentrations of $\mathrm{CO}_{2}$ and from lower to higher concentrations at the transition 
period from larvae to juvenile. For individuals exposed to $\sim 390$ and $1500 \mu \mathrm{atm} \mathrm{CO}_{2}$ for the first 24 days of development, there was a significant effect of $\mathrm{CO}_{2}$ on total survival $(p<0.001$; ANOVA $)$ as survival at $\sim 390$ was $37 \pm 3.3 \%$ and at $\sim 1500$ was $23 \pm 1.8 \%$ (Fig. 5a). At day 24 , a subset of individuals were moved from low $\mathrm{CO}_{2}$ $(\sim 390 \mu \mathrm{atm})$ to high $\mathrm{CO}_{2}(\sim 1500 \mu \mathrm{atm})$ and from high $\mathrm{CO}_{2}(\sim 1500 \mu \mathrm{atm})$ to low $\mathrm{CO}_{2}(\sim 390 \mu \mathrm{atm})$. Survival from day 24-36 was also significantly affected by $\mathrm{CO}_{2}(p<0.001$; ANOVA; Fig. 5b). Percent survival of M. mercenaria at $36 \mathrm{~d}$ exposed to $390 \mu \mathrm{atm} \mathrm{CO}_{2}, 390$ switched to $1500 \mu \mathrm{atm}$ $\mathrm{CO}_{2}, 1500$ switched to $390 \mu \mathrm{atm} \mathrm{CO}_{2}$, and $1500 \mu \mathrm{atm} \mathrm{CO}_{2}$ $70.31 \pm 9.02,62.5 \pm 10.21,97.5 \pm 2.04$, and $43.09 \pm 4.72 \%$, respectively (Fig. 5b).

\subsection{Juvenile $A$. irradians growth following larval stage exposed to high $\mathrm{CO}_{2}$}

To assess the longer-term effects of elevated $\mathrm{CO}_{2}$ exposure during larval development, the growth of post-set larvae was measured over a ten-month period. For A. irradians growth during the first 12 weeks post-spawning, larval stage $\mathrm{CO}_{2}$ exposure had a significant effect on specific growth rates $(p<0.001$; ANOVA; Fig. 6$)$. With increasing $\mathrm{CO}_{2}$ treatments during the larval stage development from $\sim 250$ to 390 to 750 , specific growth rates for weeks $0-12$ decreased from $0.25 \pm 0.0008$ to $0.23 \pm 0.008$ to $0.21 \pm 0.0005 \mathrm{~mm}$ week $^{-1}$ respectively (Fig. 6). For weeks 13-26, these trends reversed as individuals reared under $\sim 250,390$, and $750 \mu$ atm as larvae displayed specific growth rates of $0.009 \pm 0.001,0.014 \pm 0.001$, and $0.02308 \pm 0.001 \mathrm{~mm}^{2}$ week $^{-1}$ respectively (Fig. 6). While shell diameters of individuals metamorphosed under $\sim 390$ and $750 \mu \mathrm{atm} \mathrm{CO}_{2}$ were $16.19 \pm 0.24$ and $13.07 \pm 0.08 \mathrm{~mm}$ in September 2010, they were similar in size by December 2010 ( $21 \mathrm{~mm}$; Fig. 7). However, at the end of the 10-month experiment, individuals reared at $250 \mu \mathrm{atm} \mathrm{CO}_{2}$ as larvae and early stage juveniles were significantly larger than individuals exposed to 390 and $750 \mu$ atm ( $p<0.05$; ANOVA; Fig. 8).

\section{Discussion}

It has been well established that bivalve larvae experience reduced growth and survival when exposed to elevated concentrations of $\mathrm{CO}_{2}$ (e.g., Miller et al., 2009; Talmage and Gobler, 2009, 2010; Barton et al., 2012). In this study, experiments examining net calcification rates and RNA:DNA ratios provided insight regarding specific physiological processes that are impacted by elevated $\mathrm{CO}_{2}$. Other experiments demonstrated that high $\mathrm{CO}_{2}$ exposure during the first four days of development alone can inhibit larval growth while exposure during the final 10 days does not. Finally, experiments established the juvenile stage implications of larval stage exposure to elevated concentrations of $\mathrm{CO}_{2}$ for the bi-
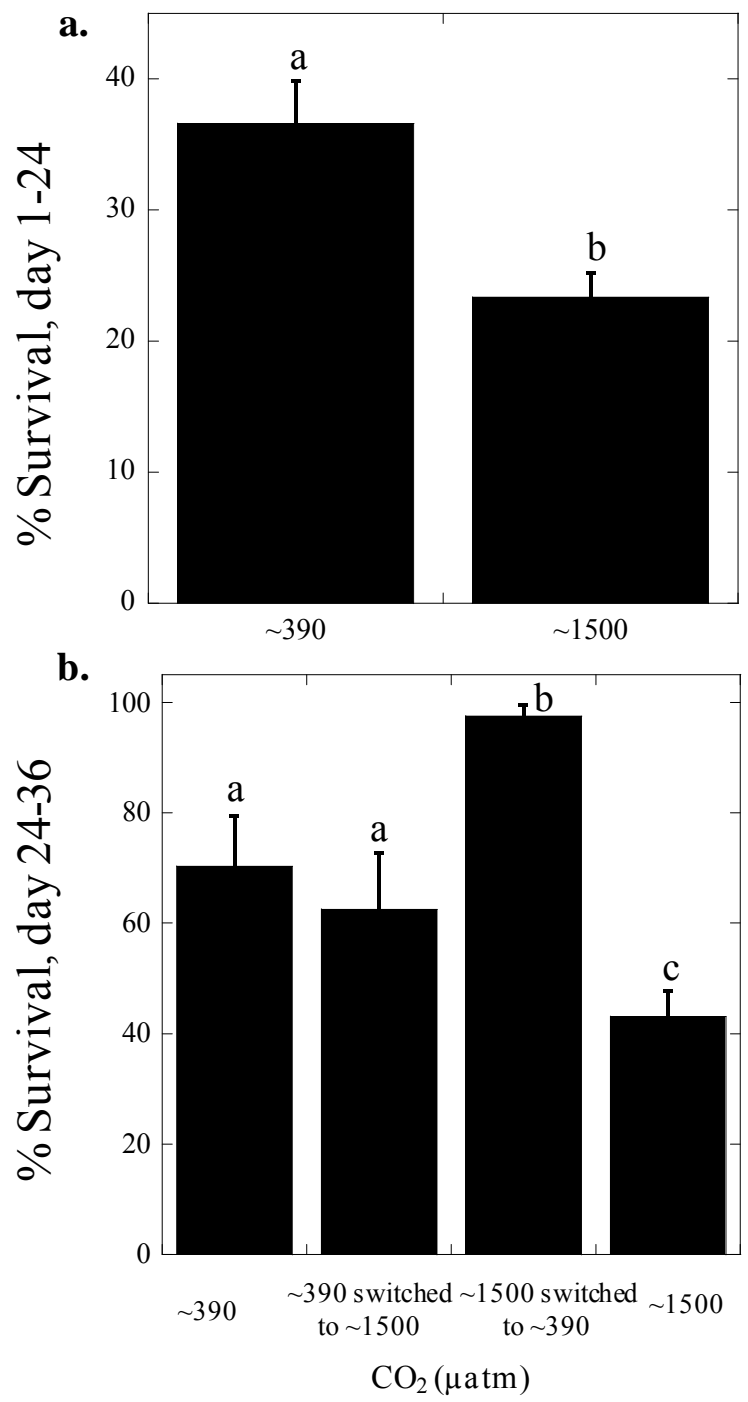

Fig. 5. (a) Percent survival of Mercenaria mercenaria exposed to 390, and $1500 \mu \mathrm{atm} \mathrm{CO}_{2}$ during larval development (Table 5). (b) Percent survival of post-set, juvenile $M$. mercenaria under four treatments of $\mathrm{CO}_{2}$ : individuals exposed to $390 \mu$ atm since fertilization; individuals exposed to $390 \mu \mathrm{atm}$ as larvae and increased to 1500 at day 24 ; individuals exposed to $1500 \mu \mathrm{atm}$ as larvae and decreased to $390 \mu \mathrm{atm}$ at day 24 ; and individuals exposed to $1500 \mu \mathrm{atm}$ since fertilization. Values are means $\pm 1 \mathrm{SD} ; n=4$ per treatment. Letters indicate significant differences revealed from Tukey post hoc multiple comparisons, $p \leq 0.05$ for all.

valves. Collectively, this data set provides novel insight regarding the short- and long-term implications of larval stage $\mathrm{CO}_{2}$ exposure for calcifying bivalves.

At $\mathrm{CO}_{2}$ concentrations exceeding $\sim 250 \mu \mathrm{atm}$, both $\mathrm{Mer}$ cenaria mercenaria (hard clam) and Argopecten irradians (bay scallop) larvae displayed significant declines in calcium uptake and presumably rates of net calcification. This observation is consistent with the thinner shells displayed by these bivalve larvae when exposed to higher $\mathrm{CO}_{2}$ concentrations 


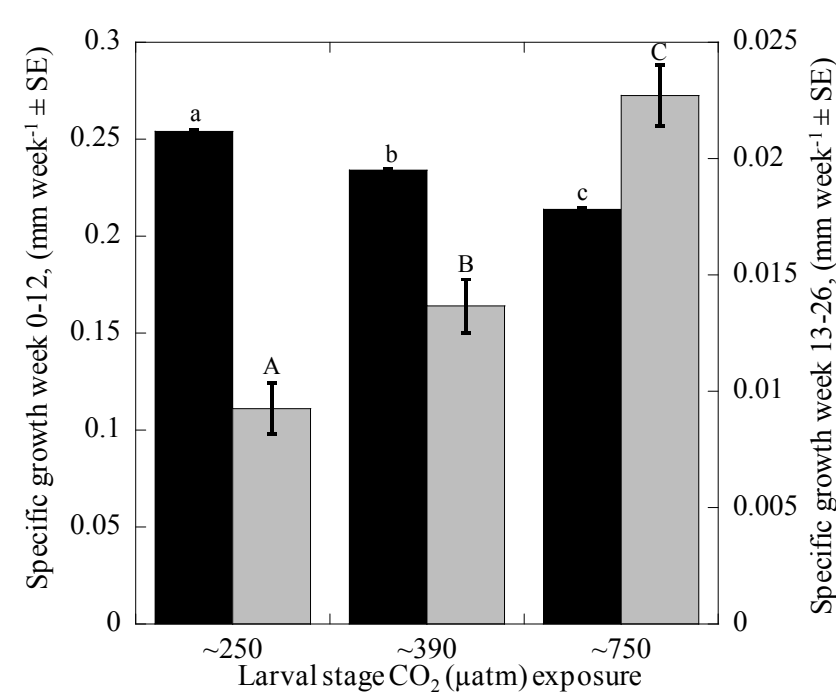

Fig. 6. Specific growth rates of Argopecten irradians for 0-12 weeks (black bars) and for 13-26 weeks (gray bars). Larvae $(n=1000)$ were grown under three $\mathrm{CO}_{2}$ concentrations $(250,390$, and $750 \mu$ atm $\mathrm{CO}_{2}$; Table 6) during the larval stages before introduced into the field as juveniles. For Tukey multiple comparisons, $p \leq 0.05$ for all. Capitalized letters indicate a separate analysis.

(Talmage and Gobler, 2010). The integrity of the bivalve shell may be one of the most important lines of defense for larval shellfish. Bivalve larvae depend on shells to provide physical support for soft and delicate internal organs, for protection from impact with suspended particles and physical stress (Carriker, 1986) and for protection from some benthic and pelagic predators (Purcell et al., 1991; Carriker, 1996). Therefore, the declines in net calcification observed with increasing $\mathrm{CO}_{2}$ levels likely contribute to larval bivalve shellfish mortality and, thus, could be considered a primary impact of ocean acidification on these organisms. Reductions in calcification under acidified ocean conditions have already been described for post-larval hard clam Mercenaria spp. that displayed decreased calcification rates with decreases in seawater $\mathrm{pH}$ (Waldbusser et al., 2010). Juvenile bivalves and larvae from the oyster species, Saccostrea glomerata, have displayed compromised shell integrity with decreasing calcium carbonate saturation states (Green et al., 2009; Watson et al., 2009). Juveniles spending only four days at undersaturated levels of calcium carbonate displayed signs of dissolution or shell pitting of the ostracum, with most dissolution of the surface shell in the umbonal region or the part of the shell that was deposited first (Green et al., 2009). These reductions in calcification by juvenile bivalves coupled with the current findings of reduced bivalve larvae calcification with increasing $\mathrm{CO}_{2}$ collectively support the "death by dissolution" hypothesis proposed as the underlying mechanism for how acidified waters and sediments lead to reduced survival rates for early life stages of calcifying bivalves (Green et al., 2009). Different forms of calcium carbonate are se-

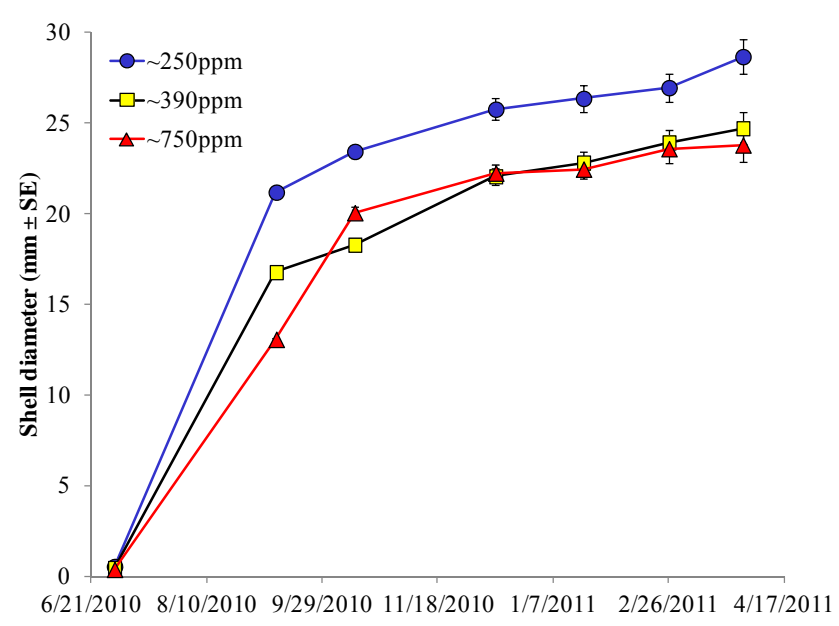

Fig. 7. Shell diameter for Argopecten irradians juveniles over a 26week period in an estuary in East Hampton, NY. Larvae $(n=1000)$ were first grown under $\mathrm{CO}_{2}$ concentrations of approximately 250, 390 , and $750 \mu \mathrm{atm} \mathrm{CO}_{2}$ (Table 6) during the larval stages before introduced into the field as juveniles. Estimates for first time point are from Sect. 3. Values are means \pm 1 SE.

creted by bivalve larvae as they develop. Larval shells begin as amorphous calcium carbonate (ACC), which is significantly more soluble than aragonite and the combinations of aragonite and calcite synthesized by later stage bivalves (Weiss et al., 2002). Even the most resistant forms of calcite dissolve under high levels of $\mathrm{CO}_{2}$ and leave organisms with shell loss (Harper, 2000). Hence, the dissolution and/or inhibition of calcification during larval stages contribute towards thin and frail shells. While thinner shells alone may leave larvae vulnerable to enhanced mortality rates, it is likely that the enhanced bioenergetic investment made to calcify under high levels of $\mathrm{CO}_{2}$ also promotes mortality. Calcification is a significant metabolic cost for marine organisms, with other metabolic costs including but not limited to the energy committed to the production of the organic matrix and somatic growth (Palmer 1992). If the shells of bivalve larvae are more difficult to synthesize under increasing $\mathrm{CO}_{2}$ levels and thus synthesized at slower rates, this may make less energy available for growth and development for larvae and, thus, could contribute to later stage mortality. The enhanced energetic investment has been evident from reduced lipid stores in larvae exposed to high $\mathrm{CO}_{2}$ (Talmage and Gobler, 2010). This would represent a secondary effect of high $\mathrm{CO}_{2}$ for surviving larvae: individuals that do not perish from high $\mathrm{CO}_{2}$ are under enhanced physiological stress since more energy may be allocated to calcification and less is available for maintenance and growth. This is consistent with the observations of Melzner et al. (2011) who reported that mussels with ample food supply were able to resist dissolution under high $\mathrm{CO}_{2}$ while those on a restricted diet could not. This is also consistent with reported higher metabolic rates in juvenile oysters, Crassostrea virginica, exposed to elevated $\mathrm{CO}_{2}$ indicating a 
higher energy demand of homeostasis under these conditions (Beniash et al., 2010). The additional stressors that coastal bivalve larvae encounter in parallel with acidification such as elevated temperatures and harmful algae are likely to exacerbate energy demands and further depress survival rates (Parker et al. 2010; Talmage and Gobler, 2011; 2012).

The hypothesis that reduced calcification rates have "trickle down" effects on larval physiology and performance was supported by measurements of RNA : DNA ratios. RNA transcribes the genetic material stored in DNA and is subsequently translated by ribosomes to synthesize proteins. Hence, high levels of RNA compared to DNA are indicative of an organism in an active state of transcribing RNA, synthesizing proteins, and growth (Malzahn et al., 2003). Under high concentrations of $\mathrm{CO}_{2}$, the ratio of RNA : DNA was reduced for both species of larvae, suggesting that rates of transcription and growth were compromised. This conclusion was supported by the high degree of correlation between RNA : DNA ratios and shell-based growth rates of $M$. mercenaria $\left(r^{2}=0.92 ; p=0.08\right)$ and $A$. irradians larvae $\left(r^{2}=0.99, p<0.01\right)$. The reduced RNA : DNA ratios displayed by individuals developing under high levels of $\mathrm{CO}_{2}$ indicates the systemic negative impact of ocean acidification on these organisms.

Most ocean acidification experiments conducted to date have administered a static exposure of specific $\mathrm{CO}_{2}$ concentrations to organisms (Doney et al., 2009). In an ecosystem setting, however, it is likely that marine organisms, in general (and estuarine larvae, in particular), will experience varying $\mathrm{CO}_{2}$ concentrations due to tidal effects, diurnal fluctuations in photosynthesis, and seasonal changes associated with temperature (Melzner et al., 2012). By varying $\mathrm{CO}_{2}$ levels, this study found that individuals of $A$. irradians grown at "normal" $\mathrm{CO}_{2}$ levels $(\sim 390 \mu \mathrm{atm})$ at the start of the larval cycle were able to withstand a longer exposure period at higher $\mathrm{CO}_{2}$ (approximately $10 \mathrm{~d}$ ) before significant declines in survival occurred. In contrast, individuals that began their development at higher $\mathrm{CO}_{2}$ experienced significant declines in survival after only four days. This demonstrates that the first days of development are the most sensitive exposure period for A. irradians larvae, perhaps because more soluble forms of calcium carbonate are secreted by larvae during this period (Weiss et al., 2002) or because there is not internal compartmentalization for calcification at this time (Gillikin et al., 2007). Regardless of the mechanism, this result further suggests that shellfish hatcheries and restoration efforts should focus efforts on ensuring ideal chemical conditions for the first week of bivalve larval development. Importantly, however, the benefits of initial development under normal $\mathrm{CO}_{2}$ levels are not enough to protect against extended, later exposure to high $\mathrm{CO}_{2}$ as exposure to $750 \mu$ atm $\mathrm{CO}_{2}$ for 13 days after six days of optimal $\mathrm{CO}_{2}$ caused a significant decline in larval survival. Given the in situ variability of $\mathrm{CO}_{2}$ concentrations, this experimental increase in $\mathrm{CO}_{2}$ from ambient $(\sim 390 \mu \mathrm{atm})$ to elevated $\mathrm{CO}_{2}$ concentrations $(\sim 750 \mu \mathrm{atm})$ mimics what these larvae may experience as they develop from pediveligers into juveniles and settle onto the seafloor. Given that changes in $\mathrm{CO}_{2}$ levels administered during these experiments occurred over days or weeks, future experiments should focus on the effects of diel changes of $\mathrm{CO}_{2}$ concentrations on larval bivalves.

While larval exposure to high $\mathrm{CO}_{2}$ can have strong negative impacts on growth and survival of many marine animals (Miller et al., 2009; Talmage and Gobler, 2009, 2010; Dupont et al., 2010; Barton et al., 2012), the post-larval stage implications of this exposure have not been fully established. Hettinger et al. (2012) reported that the Olympia oyster (Ostrea lurida) juveniles that had been reared as larvae under reduced $\mathrm{pH}$ experience significantly decreased shell growth rate regardless of the $\mathrm{pH}$ level the oysters experienced as juveniles, indicating a strong carry-over effect from the larval phase. During the current study, after 24 days of exposure to ambient and high $\mathrm{CO}_{2}$ concentrations, $M$. mercenaria larvae displayed significantly higher survival under lower $\mathrm{CO}_{2}$ concentrations $(\sim 390 \mu \mathrm{atm})$. When a subset of the surviving individuals were moved from high to low and low to high $\mathrm{CO}_{2}$ concentrations, however, the highest survival rate over the next two weeks was found among individuals that developed under high $\mathrm{CO}_{2}(\sim 1500 \mu \mathrm{atm})$ as larvae and then were reared at $\sim 390 \mu \mathrm{atm} \mathrm{CO}_{2}$ as juveniles (Fig. 5b). As broadcast spawners, bivalves produce cohorts of larvae derived from multiple parents that are likely to display plasticity in their general fitness (Kraeuter and Castagna, 2001; Cragg, 2006). Although high $\mathrm{CO}_{2}$ eliminated $80 \%$ of the larval cohort, individuals that survived this treatment displayed superior survival rates as early stage juveniles suggesting high $\mathrm{CO}_{2}$ may eliminate generally weaker individuals. Moreover, this finding indicates that individuals reared under high $\mathrm{CO}_{2}$ as larvae can experience compensatory growth when the stress of elevated $\mathrm{CO}_{2}$ levels is removed.

The effects of $\mathrm{CO}_{2}$ exposure on calcifying invertebrates can transcend life stages (Dupont et al., 2012; Hettinger et al. 2012; Parker et al., 2012). The superior performance of individuals exposed to high $\mathrm{CO}_{2}$ as larvae and reared under normal conditions as juveniles was also evident in A. irradians potentially evidencing a physiological plasticity. Although A. irradians bivalves had the greatest specific growth at the lowest $\mathrm{CO}_{2}$ concentration during the larval stage, individuals surviving the highest $\mathrm{CO}_{2}$ level experienced the highest specific growth rates as juveniles, although these rates were an order of magnitude lower than those displayed by larvae. This finding supports the hypothesis that individuals that survive high $\mathrm{CO}_{2}$ as larvae are, on average, more fit as juveniles than individuals exposed to normal $\mathrm{CO}_{2}$ levels as larvae. The compensatory, juvenile stage growth displayed by individuals reared under high $\mathrm{CO}_{2}$ as larvae resulted in their size differences being eliminated after two months of growth under normal $\mathrm{CO}_{2}$ conditions. Interestingly, while the growth rate of the individuals reared at ambient and high $\mathrm{CO}_{2}(\sim 390$ and $750 \mu \mathrm{atm})$ outpaced those of the lowest $\mathrm{CO}_{2}$ treatment 
( $\sim 250 \mu \mathrm{atm})$ as early stage juveniles, they did not overcome the deficit in size established during the larval stage after ten months of growth under normal $\mathrm{CO}_{2}$. Given that smaller juvenile bivalves are more susceptible to predators than larger individuals (Kraeuter, 2001), this finding suggests that the negative effects of larval stage exposure to even modern-day levels of $\mathrm{CO}_{2}$ represent a legacy that can persist for at least eight months in an ecosystem setting. This finding is similar to the 1.5 month carry-over effect of larval stage $\mathrm{CO}_{2}$ exposure in juvenile Olympic oyster growth reported by Hettinger et al. (2012) and further emphasizes the critical role larval stage $\mathrm{CO}_{2}$ exposure can play in influencing the success of modern-day bivalve populations.

Acknowledgements. We are grateful for the supply of Mercenaria mercenaria and Argopecten irradians larvae from Cornell Cooperative Extension, Southold, NY and from the East Hampton Shellfish Hatchery, East Hampton, NY. Juveniles of all three species were provided from the East Hampton Shellfish Hatchery. We are grateful to Lucas Merlo and Theresa K. Hattenrath-Lehmann for their assistance with the spectrophotometric $\mathrm{pH}$ measurements. This research was supported by the NOAA's Ocean Acidification Program through award \#NA12NOS4780148 from the National Centers for Coastal Ocean Science and the New Tamarind Foundation.

Edited by: J.-P. Gattuso

\section{References}

Albright, R., Mason, B., and Langdon, C.: Effect of aragonite saturation state on settlement and post-settlement growth of Porites astreoides larvae, Coral Reefs, 27, 485-490, 2008.

Barton, A., Hales, B., Waldbusser, G. G., Langdon, C., and Feely, R. A.: The Pacific oyster, Crassostrea gigas, shows negative correlation to naturally elevated carbon dioxide levels: implications for near-term ocean acidification effects, Limnol. Oceanograph. 57, 698-710, 2012.

Beniash, E., Ivanina, A., Lieb, N. S., Kurochkin, I., and Sokolova, I.M.: Elevated level of carbon dioxide affects metabolism and shell formation in oysters Crassostrea virginica, Mar. Ecol. Prog. Ser., 419, 95-108, 2010.

Cai, W. J., Hu, X. P., Huang, W. J., Murrell, M. C., Lehrter, J. C., Lohrenz, S. E., Chou, W. C., Zhai, W. D., Hollibaugh, J. T., Wang, Y. C., Zhao, P. S., Guo, X. H., Gundersen, K., Dai, M. H., and Gong, G. C.: Acidification of subsurface coastal waters enhanced by eutrophication, Nat. Geosci., 4, 766-770, 2011.

Carriker, M. R.: Influence of suspended particles on biology of oyster larvae in estuaries, American Malacological Bull., 3, 41-49, 1986.

Carriker, M. R.: The shell and ligament, in: The Eastern oyster: Crassostrea virginica, edited by: Kennedy, V. S., Newwell, R. I. E., Eble, A. E., Maryland Sea Grant College, University of Maryland System, College Park, MD., 75-168, 1996.

Castell, L. L. and Mann, R.: Optimal staining of lipids in bivalve larvae with Nile Red, Aquaculture, 119, 89-100, 1994.
Clemmesen, C.: The effect of food avaiability, age or size on the RNA : DNA ratio of individually measured herring larvae - laboratory calibration, Mar. Biol., 118, 377-382, 1994.

Comeau, S., Gorsky, G., Alliouane, S., and Gattuso, J. P.: Larvae of the pteropod Cavolinia inflexa exposed to aragonite undersaturation are viable but shell-less, Mar. Biol., 157, 2341-2345, 2010.

Cragg, S. M.: Development, physiology, behaviour, and ecology of scallop larvae, in: Scallops: Biology, ecology, and aquacultureedited by: Shumway, S. E., Parsons, G. J., Elsevier, 45-122, 2006.

Dempster, E. L., Pryor, K. V., Francis, D., Young, J. E., and Rogers, H. J.: Rapid DNA extraction from ferns for PCR-based analyses, Biotechniques, 27, 66-68, 1999.

Dickson, A. G.: pH buffers for sea-water media based on the total hydorgen-ion concentration scale, Deep-Sea Res Pt. I, 40, 107$118,1993$.

Dickson, A. G., Sabine, C. L., and Christian, J. R.: Guide to best practices for ocean $\mathrm{CO}_{2}$ measurements, PICES Special Publication, 3, 191 pp., 2007.

Doney, S. C., Fabry, V. J., Feely, R. A., and Kleypas, J. A.: Ocean acidification: the other $\mathrm{CO}_{2}$ problem, Ann. Rev. Mar. Sci., 1, 169-192, 2009.

Dupont, S., Ortega-Martinez, O., and Thorndyke, M.: Impact of near-future ocean acidification on echinoderms, Ecotoxicol., 19, 449-462, 2010.

Dupont, S., Dorey, N., Stumpp, M., Melzner, F., Thorndyke, M. Long-term and translife- cycle effects of exposure to ocean acidification in the green sea urchin Strongylocentrotus droebachiensis, Mar. Biol., doi:10.1007/s00227-012-1921-x, 2012.

Feely, R. A., Sabine, C. L., Hernandez-Ayon, J. M., Ianson, D., and Hales, B.: Evidence for upwelling of corrosive "acidified" water onto the continental shelf, Science, 320, 1490-1492, 2008.

Gillikin, D. P., Lorrain, A., Meng, L., and Dehairs, F.: A large metabolic carbon contribution to the delta $\mathrm{C}-13$ record in marine aragonitic bivalve shells, Geochim. Cosmochim. Ac., 71, 29362946, 2007.

Green, M. A., Waldbusser, G. G., Reilly, S. L., Emerson, K., and O'Donnell, S.: Death by dissolution: sediment saturation state as a mortality factor for juvenile bivalves, Limnol. Oceanograph., 54, 1037-1047, 2009.

Harper, E. M. Are calcitic layers an effective adaptation against shell dissolution in the Bivalvia?, J. Zoology, 251, 179-186, 2000.

Hettinger, A., Sanford, E., Hill, T. M., Russell, A. D., Sato, K. N. S., Hoey, J., Forsch, M., Page, H., and Gaylord, B.: Persistent carry-over effects of planktonic exposure to ocean acidification in the Olympia oyster, Ecol., doi:10.1890/12-0567.1, 2012.

Ho, M. S. and Zubkoff, P. L.: The calcium uptake by larvae of the oyster, Crassostrea virginica, and the clam, Mulinia lateralis, Comparative Biochem. Physiol. 6, 143-146, 1980.

I IPCC: Climate Change 2007: The Physical Science Basis. Contribution of Working Group I to 20 the Fourth Assessment. Report of the Intergovernmental Panel on Climate Change., in: Biology of larvae and spat, edited: Kennedy, V. S., Newell, R. I. E., and Eble, A. E., The Eastern Oyster, Crassostrea virginica, Maryland Sea Grant, 371-411, 1996.

Kraeuter, J. N.: Predators and predation, Chapter 11, in: Biology of the Hard Clam, edited by: Kraeuter, J. N. and Castagna. M., Elsevier, New York, 441-589, 2001. 
Kraeuter, J. N. and Castagna, M.: Biology of the Hard Clam, Elsevier, 228-241, 2001.

Malzahn, A. M., Aberle, N., Clemmesen, C., and Boersma, M.: Nutrient limitation of primary producers affects planktivorous fish condition, Limnol. Oceanogr., 52, 2062-2071, 2007.

Malzahn, A. M., Clemmesen, C., and Rosenthal, H.: Temperature effects on growth and nucleic acids in laboratory-reared larval coregonid fish, Mar. Ecol. Progr. Ser., 259, 285-293, 2003.

Melzner, F., Stange, P., Trubenbach, K., Thomsen, J., Casties, I., Panknin, U., Gorb, S. N., and Gutowska, M. A.: Food supply and seawater $p \mathrm{CO}_{2}$ impact calcification and internal shell dissolution in the blue mussel Mytilus edulis, PLoS One, 6, e24223, doi:10.1371/journal.pone.0024223, 2011.

Miller, A. W., Reynolds, A. C., Sobrino, C., and Riedel, G. F.: Shellfish face uncertain future in high $\mathrm{CO}_{2}$ world: Influence of acidification on oyster larvae and growth in estuaries, PLoS One, 4, e5661, doi:10.1371/journal.pone.0005661, 2009.

Orr, J. C., Fabry, V. J., Aumont, O., Bopp, L., Doney, S. C., Feely, R. A., Gnanadesikan, A., Gruber, N., Ishida, A., Joos, F., Key, R. M., Lindsay, K., Maier-Reimer, E., Matear, R., Monfray, P., Mouchet, A., Najjar, R. G., Plattner, G. K., Rodgers, K. B., Sabine, C. L., Sarmiento, J. L., Schlitzer, R., Slater, R. D., Totterdell, I. J., Weirig, M. F., Yamanaka, Y., and Yool, A.: Anthropogenic ocean acidification over the twenty-first century and its impact on calcifying organisms, Nature, 437, 681-686, 2005.

Palmer, A. R.: Calcification in marine mollusks: how costly is it?, Proc. Natl. Acad. Sci. U. S. A., 89, 1379-1382, 1992.

Parker, L. M., Ross, P. M., and O'Connor, W. A.: Comparing the effect of elevated $p \mathrm{CO}_{2}$ and temperature on the fertilization and early development of two species of oysters, Mar. Biol., 157, 2435-2452, 2010.

Parker, L. M., Ross, P. M., O’Connor, W. A., Borysko, L., Raftos, D. A., Pörtner, H.: Adult exposure influences offspring response to ocean acidification in oysters, Global Change Biol. 18, 82-92, 2012.

Purcell, J. E., Cresswell, F. P., Cargo, D. G., and Kennedy, V. S.: Differential ingestion and digestion of bivalve larvae by the scyphozoan Chrysaora quinquecirrha and the ctenophore Mnemiopsis leidyi, Biol. Bull., 180, 103-111, 1991.

Roy, R. N., Roy, L. N., Vogel, K. M., Porter-Moore, C., Pearson, T., Good, C. E., Millero, F. J., and Campbell, D. M.: The dissociation constants of carbonic acid in seawater at salinities 5 to 45 and temperatures 0 to $45^{\circ} \mathrm{C}$, Mar. Chem., 44, 249-267, 1993.
Sabine, C. L., Feely, R. A., Gruber, N., Key, R. M., Lee, K., Bullister, J. L., Wanninkhof, R., Wong, C. S., Wallace, D. W. R., Tilbrook, B., Millero, F. J., Peng, T. H., Kozyr A. T., and Rios, A. F.: The oceanic sink for anthropogenic $\mathrm{CO}_{2}$, Science, 305, 367-371, 2004.

Salisbury, J., Green, M. A., Hunt, C., and Campbell, J.: Coastal acidification by rivers: a new threat to shellfish?, Eos Trans AGU, 89, 513, 2008

Sverdrup, H. U.: The oceans: their physics, chemistry and general biology, Prentice-Hall, 1942.

Talmage, S. C. and Gobler, C. J.: The effects of elevated carbon dioxide concentrations on the metamorphosis, size, and survival of larval hard clams (Mercenaria mercenaria), bay scallops (Argopecten irradians), and Eastern oysters (Crassostrea virginica), Limnol. Oceanogr., 54, 2072-2080, 2009.

Talmage, S. C. and Gobler, C. J.: Effects of past, present, and future ocean carbon dioxide contrations on the growth and survival of larval shellfish, Proc. Natl. Acad. Sci. USA., 107, 17246-17251, 2010.

Talmage, S. C. and Gobler, C. J.: Effects of elevated temperature and carbon dioxide on the growth and survival of larvae and juveniles of three species of Northwest Atlantic bivalves, PLoS One, 6, e26941, doi:10.1371/journal.pone.0026941, 2011.

Talmage, S. C., Gobler, C. J.: Effects of carbon dioxide and a harmful alga (Aureococcus anophagefferens) on the growth and survival of larval oysters (Crassostrea virginica) and scallops (Argopecten irradians), Mar. Ecol. Prog. Ser., 464, 121-134, 2012.

Waldbusser, G. G., Bergschneider, H., and Green, M. A.: Sizedependent $\mathrm{pH}$ effect on calcification in post-larval hard clam Mercenaria spp., Mar. Ecol. Prog. Ser., 417, 171-182, 2010.

Walther, K., Anger, K., and Portner, H. O.: Effects of ocean acidification and warming on the larval development of the spider crab Hyas araneus from different latitudes (54 degrees vs. 79 degrees N), Mar. Ecol. Prog. Ser., 417, 159-170, 2010.

Watson, S. A., Southgate, P. C., Tyler, P. A., and Peck, L. S.: Early larval development of the Sydney rock oyster Saccostrea glomerata under near-future predictions of $\mathrm{CO}_{2}$ driven ocean acidification, J. Shellfish Res., 28, 431-437, 2009.

Weiss, I. M., Tuross, N., Addadi, L., and Weiner, S.: Mollusc larval shell formation: Amorphous calcium carbonate is a precursor phase for aragonite, J. Exp. Zool. 293, 478-491, 2002. 